\title{
SPANISH BIBLICAL HEBREW MANUSCRIPTS
}

The Jews were already in Spain in the Roman period. The earliest epigraphic data available to us dates back to the I-II century A.D., with a trilingual inscription on a stone conserved in the Sephardic Museum in Toledo. These Jewish communities which were already established in Roman times, continued to grow and became numerous and widespread during the Visigoth period. It is after the Arab conquest that the Jews gained in importance and studies into the Hebrew language and the Bible began to flourish in Spain.

In the tenth century the especially careful and thorough Spanish manuscripts were already well known for the care with which they were written. Significantly, S. G. Stern cites "those ancient and thorough Spanish Bibles"1 the Spanish Jews, mentions that "Their biblical texts were regarded as more accurate and authoritative.”2 Menahem ha-Meirí talks of Rabbi Samuel ben Jacob who travelled from Germany to Toledo to purchase a copy of the Pentateuch since it had been written in conformity with the laws governing the writing of a Sefer Torah. ${ }^{3}$ Elías Levita states in his Massoreth ha-Massoreth that "...most of the correct Codices I found to be Spanish, and it is upon these that I relied, and it is their method that I followed."4

The commentators Menahem de Lozano (1550-before 1624) and Y.S.de Norzi (15601616) particularly appreciated the Spanish manuscripts and made this perfectly clear in their commentaries. The former states in his work 'Ôr Tôrah: “...I knew that these misinterpretations were to be found in the Ashkenazim codices...but these codices are not

\footnotetext{
${ }^{1}$ S. G. Stern, Teshubôt talmidê Menahem ben Sarûq ‘al dibrê Dunash ben Labrat (Viena 1870) p. 67.

${ }^{2}$ H. J. Zimmels, Ashkenazim and Sephardim (London 1958) p. 145.

${ }^{3}$ IDEM, p. 138.

${ }^{4}$ Ch. D. Ginsburg, The Massoreth ha-Massoreth of Elias Levita... in Hebrew, with an English Translation (New York) 1968 p. 93.
} 
available to us, but those of Sephardim are and they are very precise. ${ }^{5}$ Norzi refers to them frequently in his Min lat vay as an example of the most accurate readings.

In his Introduction to the Massoretico-Critical Edition of the Hebrew Bible Ginsburg states “...Toledo from where emanated nearly all the oldest, the most costly and the most accurate Standard Codices, as is attested by the treasures in the different Libraries in Europe..” and he later continues: “..no printed copy could at that time equal in beauty and accuracy the manuscripts which were produced in Spain.”6

It is, therefore, no surprising that Spanish manuscripts were used in such important tasks as the composition of the Complutensian Polyglot Bible and also for the Antwerp Bible by Arias Montano. The M1 manuscript in the Complutensian University of Madrid (UCM) and G-II-8 in El Escorial are good examples of this. The former was the basic text for the Complutensian Polyglot Bible and the latter was used, together with others, for the Antwerp Bible.

The majority of the Hebrew manuscripts in Spain are to be found in these libraries and in the National Library in Madrid. There is no single, general catalogue of these codices, but rather several catalogues from some of the libraries that house these texts. Many of these catalogues were published a long time ago and are in need of revision and updating. ${ }^{7}$

\footnotetext{
${ }^{5}$ M.T. Ortega Monasterio, Texto hebreo bíblico de Sefarad en el 'Ôr Tôrah de Menahem de Lonzano (Madrid 1980) p. 41.

${ }^{6}$ Ch. D. Ginsburg, Introduction to the Massoretico-Critical Edition of the Hebrew Bible (New York 1966) pp. 906-925.

7 Among the catalogues, lists and descriptions, see especially: J. Villa-Amil y Castro, Catálogo de los manuscritos existentes en la Biblioteca del Noviciado de la Universidad Central (Madrid 1878); J. Llamas, “Los manuscritos hebreos de la Universidad de Madrid”, Sefarad 5 (1945): 263-266; J. Llamas, Los manuscritos hebreos de la Real Biblioteca de San Lorenzo de El Escorial (El Escorial 1943); F. Cantera Burgos, “Manuscritos hebreo-bíblicos en España”, en Enciclopedia de la Biblia, vol. 4 (Barcelona 1963) cols. 12501269; Catálogo de la Real Biblioteca: Manuscritos (4 vols.) (Madrid 1996); N. Allony y E. Kupfer, Lista de
} 
The Villa-Amil y Castro catalogue dates back to 1878, and the Llamas catalogue of El Escorial to 1943, while that of the same author in the Complutensian University dates to 1945.

Some scholars at the "Instituto de Filología” have recently drawn up a catalogue ${ }^{8}$ based on the lists of manuscripts in three libraries: The Library of the Royal Monastery of El Escorial, The Library of the Royal Palace of Madrid and the historical "Marqués de Valdecilla” Library (which houses the former collection of the Madrid's Complutensian University). The manuscripts at these libraries were, in our opinion, those most in need of a new catalogue. We restricted our catalogue to Hebrew biblical manuscripts, biblical commentaries and grammatical works. These are the areas that are of basic interest to biblical and Hebrew scholars. This is in no way to suggest that the other thematic areas to be found in the Hebrew texts lack interest, but simply that we had to limit our field of work and that which we might call biblical Hebrew seemed to us to be the most appropriate field. We do intend to extend our work to other libraries with Hebrew manuscripts. At the moment, we are working with manuscripts in the National Library, the Royal Academy of History, the National Public Records Office and the Lázaro Galdiano Museum in Madrid.

\section{THE LIBRARY OF THE ROYAL PALACE OF MADRID}

It is safe to say that the present library of the Royal Palace of Madrid originated in the efforts of Carlos IV (1748-1819) to install the chamber library in the palace buildings. The

fotocopias de manuscritos hebreos en el Instituto. Parte $2^{a}$ : Manuscritos en las bibliotecas de Bélgica, Dinamarca, Holanda, España y Suiza (Jerusalén 1964).

${ }^{8}$ F. J. del Barco del Barco, Catálogo de manuscritos hebreos de la Comunidad de Madrid, vol. I (Madrid 2002). 
Royal Library certainly represents one of the links between the house of Austria and the Bourbons. It is also the principal source of the written works of the monarchy. The library was set up with the king's own private funds ans as such, it received special treatment.

Once the buildings were finished, the collection, made up principally from bequests and gifts offered to the king as well as others made subsequently, was installed in1761. Initial bequests included those of the Marqués de Mondéjar y de Cardona, archbishop of Valencia, and others that Felipe V brought from France; the collection was added to at later dates with bequests from Mayáns, Celestino Mutis or Francisco de Bruna, count of Gondomar as well as those that came from the College Residences of Salamanca.

Carlos IV entrusted his private library to Felipe Scio de San Miguel, a cleric in the schools for the poor, who was Fernando’s VI’s tutor, and an eminent biblical scholar. Scio de San Miguel held the position of librarian until his death in 1806. A translation of the Bible into Spanish published in six volumes has been attributed to him. ${ }^{9}$ This Bible, in its first edition, presents the Latin and Spanish texts in double columns with a series of annotations. The author states in the Disertacion preliminar that his source was the Vulgate text of Spanish bibles, such as the Ferrara Bible, as well as French bibles and certain other manuscripts from El Escorial.

There is one document, among all these other valuable documents, that is of particular interest to the scholars of Hebrew biblical manuscripts: a 16 volume bible small in size, in duodecimo (10 x 8 cms.), a valuable manuscript written on parchment. It represents the full text of the Hebrew Bible together with a series of masoretic lists for each volume at the beginning and at the end of each book. It is set out with vowel and accent markings, written in a beautiful square Sephardic hand with parva and magna masoras. It is illuminated in gold with a blue or pink background, the edges are decorated with plants motifs at the beginning of each book and in texts of special importance such as the book of

\footnotetext{
${ }^{9}$ F. Scio de San Miguel, La Santa Biblia traducida al español de la Vulgata Latina (1790-1793).
} 
Psalms. The manuscript, which has been very well conserved is dated in Toledo in 1487, but its binding -of Moroccan leather with trimmings and central motifs, golden edgings and clasps, dates from the $18^{\text {th }}$ century.

We do not know exactly when this Bible became part of the collection. There is, however, a reference in the library that sheds some light on its history. In one document, signed by the then owner of the Bible, Joseph Martínez, in Nice on 17 August 1831, he asserts that De Rossi had already taken this Bible into account when he compiled his famous Variae Lectiones and that a letter of his confirms this fact. ${ }^{10}$ There is also a reference to the opinion of Samuel Coen Rabin, a public scribe in Hebrew matters in Livorno, who asserts the excellent value of the Bible in a certificate dated in 1817. It seems that the Duke of Tuscany was interested in acquiring this manuscript and even sent experts to Livorno to examine it. Neither did it escape the visit of two Englishmen who were particularly impressed by the accuracy of the punctuation and wanted to take it back to London. The file reference shows an exact reproduction of the Hebrew colophon which appears in the eighth volume of the Bible later translated into Spanish; this translation is signed by Moisés Benzaquin, public translator, in Nice, 29 ${ }^{\text {th }}$ August 1831.

Francisco Antonio González Oña, head librarian of the Royal Public Library, endorsed these same merits and reiterated the opinions of De Rossi and Rabin. He also asserted that having compared the text, vocalization and masorah with other accredited versions such as the Antwerp Regia and the Complutensian Bible, he could attest that they had been written with great care. We can, therefore, deduce from this data that the collection came from Italy, via Nice, between $29^{\text {th }}$ August 1831 and $1^{\text {st }}$ September 1832 . We do not know, however, who acquired it or who donated it to the library.

\footnotetext{
${ }^{10}$ J. B. de Rossi, Variae Lectiones Veteris Testamenti (Parmae 1748-88). In his Prolegomenon, Pars II, Cap. IV appears this manuscript with nr. 18, being part of the library of Jacob ben Samuel Ergas in Livorno but erroneously dated in the XIV century.
} 


\section{THE LIBRARY OF THE COMPLUTENSIAN UNIVERSITY OF MADRID}

The collection of ancient documents of the Madrid Complutensian University Library is kept on the site of the former university. This collection of ancient documents comes principally from the former library of the Residencial College of San Ildefonso of the University of Alcalá de Henares. Several scholars have reviewed the collection; including most recently, Villa-Amil, José Llamas and M. Sánchez Mariana. ${ }^{11}$ There are, nevertheless, earlier references to the library where Hebrew manuscripts of the XVI and XVIII centuries are to be found.

This collection of Hebraica is of Spanish origin, principally from Toledo and contains mainly biblical codices. It constitutes a unified whole compared to other library collections and is outnumbered only by the collections in El Escorial and the National Library.

Nearly all the manuscripts were brought together in Alcalá at the beginning of the $16^{\text {th }}$ century for didactic reasons, reflecting the particular pedagogic interests Cardinal Ximenez de Cisneros and other scholars from Alcalá. Several of the manuscripts were already in the original inventories of the library while the rest, the majority, were purchased for the compilation of the Complutensian Polyglot Bible. We know that the library was made up of 1070 volumes in 1512 and that the number reached 6000 in the $17^{\text {th }}$ century. We can, therefore, be sure that the library was not intended to be large, but instead was meant to act as a specialized library with works and codices that were unique at the time. The vast

\footnotetext{
11 J. Villa-Amil y Castro, Catálogo de los manuscritos existentes en la Biblioteca del Noviciado de la Universidad Central (procedentes de la antigua de Alcalá, (Madrid 1878); J. Llamas, "Los manuscritos hebreos de la Universidad de Madrid”, Sefarad V (1945): 261-284; M. Sánchez Mariana, “Los manuscritos hebreos en la Universidad Complutense”, Actas de las jornadas extremeñas de estudios judaicos, s. 1. pp. 33-48.
} 
majority of the manuscripts that became part of the collection of the Complutensian University library came from the collection of Alfonso de Zamora. This collection was formerly part of the Residential College of San Ildefonso, one of the colleges of the Complutensian University in Alcalá.

From the $16^{\text {th }}$ century onward, Alcalá and its university brought together the best conditions for biblical studies in Sapin. This was because of the foresight of Ximenez de Cisneros, who, ahead of his time, insisted that scholars learn the original languages of the Bible in order to be able to refute, with all the relevant knowledge at one's disposal, any false interpretations or heresies. To this end he created a chair of Hebrew language at the university. This act conferred an official status on the Hebrew language for the first time and thus constituted the beginning of Hebrew Studies in Spain. From this moment on, Hebrew continued to grow in importance and in 1528, the Trilingual College was founded for the teaching of biblical languages.

It is in this context that Ximenez de Cisneros set out to compose a polyglot bible, emulating Origen's Hexapla. This Polyglot Bible presents an edition of the biblical text in its original languages set out in columns: Hebrew, Greek, Latin and Aramaic, together with a Hebrew-Latin dictionary, indices and a Hebrew grammar in the sixth and final volume. ${ }^{12}$ Due to the method used in its composition, by using several manuscripts, and the presentation of the different texts in six languages, this edition constitutes a total renewal of the biblical text, presented as a working tool for biblical scholars and theologians with a marked didactic approach. To this end, Cisneros developed the study of Hebrew, Greek and Latin, he invited the most prestigious specialists of the times to teach in Alcalá and put

\footnotetext{
${ }^{12}$ See a detailed description of the Complutensian Polyglot in Anejo a la edición facsímile de la Biblia Políglota Complutense, Valencia 1987 y M. Revilla Rico, La Políglota de Alcalá (Madrid 1917).
} 
all the means at his disposal into acquiring a good-sized collection of original Bible manuscripts.

There is unanimity among modern scholars as to the use of some of the manuscripts. Revilla, Ginsburg and Fernández Tejero are in agreement as to the use of the M1 and the M2 as models for the Hebrew text; Revilla also added other manuscripts, including 116-Z38 (lost to us today) and M7 for the same text, and M6 for the edition of the Onkelos Targum. Llamas asserted that G-I-5 and G-II-8 were used at a secondary level and several studies have shown the proximity of the Complutensian text to the aforementioned manuscripts. ${ }^{13}$ Kahle also believed that apart from the Tiberian manuscripts several Babylonian manuscripts were used indiscriminately, and thus both types of vocalization, babylonian and tiberian, would have been used. However, we have no proof of this.

The Complutensian Polyglot was printed at the press of Arnao Guillen de Brocar. This Bible became a model for both, the composition and the form of the characters, especially the Hebraic and the Chaldaic ones. The Hebrew characters are large, square and clear, a copy of the beautiful square Sephardic letters; the Chaldaic characters are somewhat smaller but keep the same form. The result is so exceptional that the Hebrew typefaces were later passed to Plantin for his press in Antwerp where they were used for the composition of the Antwerp Bible, the work of Arias Montano.

Those responsible for the Hebrew column were: Pablo Coronel, who, although originally proposed for a chair in Salamanca went to Alcalá instead; Alonso de Alcalá, who taught medicine in Salamanca and was a Latin and Greek specialist, and also Alfonso de Zamora. Zamora had an excellent knowledge of Hebrew thanks to his studies at the Jewish school in his native city of Zamora. This school was one of the best of its time.

\footnotetext{
${ }^{13}$ See the works of Pérez Castro, Fernández Tejero, Ortega Monasterio and Vegas Montaner about Manuscripts M1, M2 in the paragraph "bibliography" (13) corresponding to these manuscripts in F. J. del Barco del Barco, Catálogo de manuscritos hebreos de la Comunidad de Madrid, vol. I (Madrid 2002).
} 
Zamora, who was a convert, went on to complete his Latin and Greek studies at the University of Salamanca where he perfected his knowledge of the three languages. Two currents --the rabbinical and the humanistic and catholic-- come together in this one person. Thus, Zamora's knowledge of the Hebrew language, its grammar and rabbinical spirit and his studies in the biblical philology of the period complement each other. In the words of Pérez Castro, the importance of his work lies "in the fact that he incorporated rabbinical science into the Renaissance to the benefit of catholic exegesis.”" ${ }^{14}$ While in Salamanca, he was invited to join the group of scholars in Alcalá. His work is reflected in many different studies but he most certainly left his mark on the manuscripts which passed through his hands. Among those which we describe here are several that he copied and others with many annotations in his hand that refer to biblical chapters, first words of the books, numberings, notes in margins etc. Above all, his work embraced grammars and dictionaries. Together with Pablo Coronel he compiled the Hebrew and Chaldaic dictionary in volume VI of the Polyglot, and he was responsible for the Hebrew grammar which concluded the edition. In collaboration with Pablo Ciruelo he worked on the interlinear Latin version of Genesis and Exodus corresponding to the manuscripts M11 and M12 prepared especially for the Complutensian collection.

As for the contents of the manuscripts, the majority, as we have mentioned, are biblical. There are, however, three commentaries: the first, M18, is a commentary on the Genesis and Exodus of Abraham ibn Ezra which is copied in two different hands; the other two are commentaries by David Qim |i, one on Isaiah and the other on Isaiah and Ezekiel, M10, both with sheets supplemented by Alfonso de Zamora. The M14 is an etymological dictionary with proper names of both the old and new testaments ordered by biblical books, this is also the work of Alfonso de Zamora. Manuscripts M17 and M21 correspond to two Sefer ha-Šorašim of David Qim |i, both with notes and additions by Alfonso de

\footnotetext{
${ }^{14}$ F. Pérez Castro, El manuscrito apologético de Alfonso de Zamora (Madrid 1950) p. XXXI.
} 
Zamora. Finally, the manuscripts M18, M19 and M20 are three copies of the Sefer Miklol of David Qim li, which were occasionally supplemented and annotated by Alfonso de Zamora.

All of the manuscripts of the Complutensian University, which include Hebrew biblical text,s are written in Sephardic square letters. Those of grammatical content or commentaries use semi-cursive Sephardic characters with the exception of the M19 which is in Italian semi-cursive. Among the biblical texts, the M1 is of particular interest: it is the earliest manuscript (1280) of those in the catalogue. It reproduces the complete text of the Hebrew Bible, written in three columns with a most beautiful masora, magna and parva and with illuminated texts at the beginning of each book. ${ }^{15}$

The Hebrew Bible research team in the Institute of Philology is working on the publication of the parva and magna masoras of this manuscript, identifying the Aramaic simanîm and the biblical passages. As a first step, and to make our work easier, we started by producing a digital version of the codex and a computer programme which facilitates its use. To date, the volumes corresponding to the books of Exodus, Numbers and Deuteronomy have been published and will appear during 2004 the volumes reproducing the masoras of Leviticus and Genesis. ${ }^{16}$

\footnotetext{
${ }^{15}$ Many studies about the manuscript have been published, the most extense by E. Fernández Tejero; the more complete description can be consulted in F. J. del Barco del Barco, Catálogo de manuscritos hebreos de la Comunidad de Madrid, vol. I (Madrid 2002) pp. 109-112.

16 Azcárraga Servert, $\mathrm{M}^{\mathrm{a}}$ Josefa: Las masoras del libro de Números. Códice M1 de la Universidad Complutense de Madrid (Madrid 2001); Ortega Monasterio, Mª Teresa: Las masoras del libro de Éxodo. Códice M1 de la Universidad Complutense de Madrid (Madrid 2002); Seijas de los Ríos Zarzosa, Guadalupe: Las masoras del libro de Deuteronomio. Códice M1 de la Universidad Complutense de Madrid (Madrid 2002); Fernández Tejero, Emilia: Las masoras del libro de Génesis (forthcoming 2004); Azcárraga Servert, Mª Josefa: Las masoras del libro de Levítico (forthcoming 2004).
} 


\section{THE LIBRARY OF THE ROYAL MONASTERY OF EL ESCORIAL}

The creation of the library in the Monastery of El Escorial took a long time, more than thirty years. When Felipe II returned from the Netherlands in 1559, he had decided to bestow on the Spanish court a place that could house one of the best libraries of his time, a library to rival with that of the Vatican in Rome or the Laurentian library in Florence. To do so he was prepared to spare no expense. He surrounded himself with the best specialists of the time, from architects to bibliophiles and humanists. The excellent education he had received from his father, Carlos V, strongly influenced his thinking and resulted not only in the construction of a magnificent building, but also bestowing it with a very special cultural identity. El Escorial is a combination of the spirit of the Counter-Reformation and the Renaissance tastes of the day. In short, the library reflects the political, cultural and religious interests of the king.

This was an enormous project, but from the outset the king could counted on the collaboration of Benito Arias Montano, a humanist, biblical scholar and philologist with a broad knowledge of ancient languages. Arias Montano dedicated a great part of his life to this endeavour. ${ }^{17}$ From the very beginning he advised the king on the books and manuscripts which were necessary for the collection and he was sent especially to Rome and the Netherlands on several occasions to purchase volumes and to deal personally with the edition of the Antwerp Bible. ${ }^{18}$

\footnotetext{
${ }^{17}$ For more about Arias Montano see, among others, the following works: B. Rekers, Benito Arias Montano, (Londres/Leiden 1972); A. F. G. Bell, Benito Arias Montano (Oxford 1922); y T. González Carvajal, “Elogio histórico del Doctor Benito Arias Montano”, Memorias de la Real Academia de la Historia 7 (1932): 1-199.

${ }^{18}$ For more about the Antwerp Bible or Biblia Regia, see D. Ramos Frechilla, "La Políglota de Arias Montano”, Revista Española de Estudios Bíblicos 3 (1928): 27-54; F. Pérez Castro and L. Voet, La Biblia Políglota de
} 
Apart from being a biblical specialist, Arias Montano was also a bibliophile. His passion for books and manuscripts -and his efforts to acquire them-- can be seen in many of his letters. During the time he spent working on the Biblia Regia in the Netherlands, he continued to seek out items for the library in El Escorial as can be seen in his letters to Zayas and even to Felipe II.

The library collection came principally from the king's personal estate as well as from purchases and copies that he had acquired primarily in Flanders or Rome. Arias Montano ordered several copies of manuscripts from the Vatican Library and commissioned various copies of Hebrew documents from Pablo de Eustaquio, a scribe who he greatly admired. While in Flanders, overseeing the printing of the Biblia Regia at the prestigious press of Plantin, Arias Montano continued to acquire manuscripts for El Escorial. He received specific instructions from the ambassador in Paris, D. Francés de Ávila, who, at the behest of Felipe II, entrusted him with this mission and advised him on how to use the money made available to him. ${ }^{19}$ But the collection was growing through other purchases, donations and bequests from a number of other private collections, notably those of Juan Páez de Castro, Juan de Borja, Diego Hurtado de Mendoza, Benito Arias Montano, as well as Alfonso de Zamora. There were other volumes which had been requisitioned by the Inquisition and others whose origin was either dubious or unknown. ${ }^{20}$ As far as the Hebrew manuscripts are concerned, they are only referred to in the documents received from Diego Hurtado de Mendoza on one occasion (manuscript G-I-13 incorporated in

Amberes (Madrid 1973) and E. Fernández Tejero and N. Fernández Marcos, "La Polémica en torno a la Biblia Regia de Arias Montano”, Biblia y Humanismo (Madrid 1997) pp. 229-238.

${ }^{19}$ Instrucción: Felipe II to Arias Montano. See T.González Carvajal, “Elogio histórico del Dr. Benito Arias Montano” en Memorias de la Real Academia de la Historia, VII (Madrid 1832) pp. 143.

${ }^{20}$ G. de Andrés studied the origin of some El Escorial manuscripts in "Historia”... See the responding article of F. Pérez Castro “Los códices hebreos de la Biblioteca de El Escorial y sus antiguos inventarios”, Sefarad 32 (1972): 153-158. 
1576) and from Arias Montano, those acquired by him or from his inheritance through the bequest of Juan Páez de Castro. In the latter there were a number of Hebrew documents that were incorporated into the library in 1572. There is no indication, however, of how many were printed documents and how many were manuscripts. We only know that the GI-12 was used in the compilation of the Complutensian Polyglot Bible. Among the manuscripts kept in El Escorial library is G-I-1, one of the few Ashkenazim manuscripts in the Community of Madrid and the second oldest in date of those described here (1306). There is also the Gramática Hebrayca of Alfonso de Zamora and another grammar by Elías Levita. Another bequest which came out of the reserves of the Holy Office, bought by the Hebrew scholar Bartolomé Valverde and incorporated into the library around 1585 includes several Hebrew codices, although all but three, according to Sigüenza were destroyed in a fire in 1561. ${ }^{21}$ Following this fire , in which a great number of documents were lost, Blanco Soto drew up a list of those manuscripts, mainly the Hebrew ones, which were saved from the flames. ${ }^{22}$

Among the manuscripts in the bequest of Arias Montano the following are particularly noteworthy: the famous codex G-II-8, already mentioned ${ }^{23}$; G-I-5 which, apart from the biblical text with commentaries by Qim li, Ibn Ezra and Ben Geršom, includes a dictionary of roots by Rabbi Meir ha-Levi bar Todros Abulafia; G-III-18 which includes an allegorical commentary of Genesis which accompanies the commentary on Isaiah by Qim li; and G-II-19 with the Hebrew text of the Ketubim copied by Moisés Jacob Usillo according to the Hebrew colophon.

In a detailed study of the G-I-5, Llamas defends the theory that the codex was used directly in the preparation of the Complutensian Polyglot. He cites the following evidence:

\footnotetext{
${ }^{21}$ Fray José de Sigüenza, Fundación del Monasterio de El Escorial, Madrid 1963

${ }^{22}$ P. Blanco Soto, Los manuscritos hebreos, BRAH 95 (1929): 488ss.

${ }^{23}$ See p. 2 and p. 8.
} 
given the number of traces which are apparent, it must have passed through the hands of Alfonso de Zamora who prepared it for use in the edition. ${ }^{24}$ Zamora is responsible for the names of the biblical books and the division of the chapters and their corresponding numeration in red ink and by his hand.

If we add to all these bequests those of the Count Duke de Olivares that were incorporated in 1656, we can count 110 Hebrew manuscripts in El Escorial before the fire and 70 codices after.

As mentioned above, the cataloguing of the collection of the royal library started soon after its inauguration and while each catalogue followed different criteria, all attempted to reflect the richness and complexity of the Hebrew manuscripts kept there. Nevertheless, no one catalogue was complete and they all differed in relation to the full collection. In 1575, Antonio de Gracián began to draw up a catalogue that he would never complete. ${ }^{25}$ We also have the contributions of those scholars already mentioned, namely Arias Montano, Páez de Castro and Sigüenza. It is not until the modern era that we find the first full description of the works of the collection in the first volume of the Biblioteca Española by Rodríguez de Castro. ${ }^{26}$ This catalogue appeared between 1771 and 1776.

Gregorio de Andrés published an article in $1973^{27}$ describing the manuscripts of the Library of El Escorial in a very succinct way. He gives little information with regard to the Hebrew codices, reproducing the catalogue of 1572, which is probably the work of Antonio Gracían, and only mentions that some came from the collection of Páez de Castro.

\footnotetext{
${ }^{24}$ José Llamas, Un manuscrito desconocido, ejemplar directo del texto hebreo Complutense (Escorial 1933).

${ }^{25}$ E. Llamas Martínez, “Antonio Gracián Dantisco”, La Ciudad de Dios CCVIII 2-3 (1995): 298.

${ }^{26}$ J. Rodríguez de Castro, Biblioteca Española, II vols., (reprint) (Hildesheim-New York 1977).

${ }^{27}$ G. de Andrés, “El primer catálogo de manuscritos de la Biblioteca de El Escorial (1572)”, Homenaje a

Federico Navarro. Miscelánea de estudios dedicados a su memoria, Asociación Nacional de Bibliotecarios, Archiveros y Arqueólogos, (1973), pp. 15-38.
} 
Nehemia Allony also drew up a detailed list of the existing manuscripts in El Escorial but without full descriptions, limiting it to brief notes on the subject or content of the documents. ${ }^{28}$ Undoubtedly, the most complete work published to date on the Hebrew manuscripts of El Escorial is the Llamas catalogue which appeared in the review Sefarad. ${ }^{29}$ This, however, already dates back to $1941-1943$ and contains some errors. Since then there has been no attempt at producing a new catalogue.

As can be appreciated from this survey, the number and quality of the Spanish Hebrew manuscripts is considerable. While they are to be found in several libraries, there are three principal collections, El Escorial, the National Library and The Complutensian University which make up the philological legacy of a golden age of Spanish Hebraic studies.

\footnotetext{
${ }^{28}$ N. Allony - E. Kupfer, List of Photocopies in the Institut. Part II: Hebrew Manuscripts in the Libraries of Belgium, Denmark, the Netherlands, Spain and Switzerland (Jerusalem 1964).

${ }^{29}$ J. Llamas, “Los Manuscritos hebreos de la Real Biblioteca de El Escorial”, Sefarad I (1941): 7-43; 279-311. and III (1943), pp. 1-1-24.
} 


\section{SUMMARY}

The aim of this study is to present the most important Hebrew manuscripts conserved in the libraries of Madrid and El Escorial. The collection of Hebrew manuscripts is especially significant in the National library of Spain, the library of the Monastery of El Escorial and the Complutensian University library. Most of the manuscripts are of sephardic origin. The importance and accuracy of Spanish manuscripts has been recognized since the Middle Ages. Some of them have been used in the editing of such important Polyglot Bibles like the Complutensian Polyglot or the Antwerp Polyglot. In

order to update old catalogues from the end of the $19^{\text {th }}$ century and the first half of the $20^{\text {th }}$ century and in order to incorporate relevant data for researchers and librarians a new catalogue is being published. The first step of the work is the study of Bibles, biblical commentaries ang grammatical works. Further research must be done in the future to update the description of other Hebrew manuscripts in these libraries. 